\title{
Buprenorphine Is a Weak Partial Agonist That Inhibits Opioid Receptor Desensitization
}

\author{
Michael S. Virk, Seksiri Arttamangkul, William T. Birdsong, and John T. Williams \\ Vollum Institute, Oregon Health \& Science University, Portland, Oregon 97239
}

Buprenorphine is a weak partial agonist at $\mu$-opioid receptors that is used for treatment of pain and addiction. Intracellular and whole-cell recordings were made from locus ceruleus neurons in rat brain slices to characterize the actions of buprenorphine. Acute application of buprenorphine caused a hyperpolarization that was prevented by previous treatment of slices with the irreversible opioid antagonist $\beta$-chlornaltrexamine ( $\beta$-CNA) but was not reversed by a saturating concentration of naloxone. As expected for a partial agonist, subsaturating concentrations of buprenorphine decreased the $[\mathrm{Met}]^{5}$ enkephalin (ME)-induced hyperpolarization or outward current. When the ME-induced current was decreased below a critical value, desensitization and internalization of $\mu$-opioid receptors was eliminated. The inhibition of desensitization by buprenorphine was not the result of previous desensitization, slow dissociation from the receptor, or elimination of receptor reserve. Treatment of slices with subsaturating concentrations of etorphine, methadone, oxymorphone, or $\beta$-CNA also reduced the current induced by ME but did not block ME-induced desensitization. Treatment of animals with buprenorphine for 1 week resulted in the inhibition of the current induced by ME and a block of desensitization that was not different from the acute application of buprenorphine to brain slices. These observations show the unique characteristics of buprenorphine and further demonstrate the range of agonist-selective actions that are possible through G-protein-coupled receptors.

\section{Introduction}

Buprenorphine is a thebaine derivative used as an analgesic and as an effective alternative to methadone in the treatment of opiate dependence (West et al., 2000; Gerra et al., 2004; Vigezzi et al., 2006; Connock et al., 2007; Soyka et al., 2008). Two properties distinguish buprenorphine from other opioids. It has a bellshaped analgesic dose-response curve (Lutfy et al., 2003; Yamamoto et al., 2006) and a ceiling effect for respiratory depression (Dahan et al., 2005, 2006). Thus, buprenorphine is an attractive compound for use in clinical settings because of reduced potential for toxicity and overdose (Kakko et al., 2007, 2008; Pergolizzi et al., 2008; Hayes et al., 2008).

Buprenorphine has slow receptor association/dissociation kinetics and a half-life of $2-5 \mathrm{~h}$. These properties contribute to both a low abuse liability and minimal withdrawal symptoms during cessation (Tzschentke, 2002). Buprenorphine is a partial agonist at $\mu$-opioid receptors (MORs) (Selley et al., 1997; Yu et al., 1997; Lutfy et al., 2003) and opioid receptor-like (ORL-1) receptors (Wnendt et al., 1999; Bloms-Funke et al., 2000; Lutfy et al., 2003). It has mixed but primarily antagonistic actions on $\kappa$-opioid (KORs) and $\delta$-opioid (DORs) receptors (Sadée et al., 1982; Richards and Sadée, 1985; Kajiwara et al., 1986; Leander, 1987; Zhu et al., 1997; Huang et al., 2001). The bell-shaped dose-response curve for buprenorphine has been attributed to activation of

Received Aug. 6, 2008; revised May 4, 2009; accepted May 5, 2009.

This work was supported by National Institutes of Health Grants 1F30-DA 021466 (M.S.V.), DA016627 (S.A.), DA 10703 (W.T.B.), and DA 08163 (J.T.W.).

Correspondence should be addressed to John T. Williams, Vollum Institute, L474, Oregon Health \& Science University, 3181 Southwest Sam Jackson Park Road, Portland, OR 97239. E-mail: williamj@ohsu.edu.

DOI:10.1523/JNEUROSCI.3723-08.2009

Copyright $\odot 2009$ Society for Neuroscience $\quad$ 0270-6474/09/297341-08\$15.00/0
MORs at low doses and ORL- 1 at higher concentrations (Lutfy et al., 2003; Yamamoto et al., 2006). Although the in vivo properties of buprenorphine have been characterized, the underlying pharmacology and signaling, particularly in neurons, remains poorly understood.

Locus ceruleus (LC) neurons express both ORL-1 and MORs but not KORs or DORs. These neurons are well suited to examine MOR signaling and receptor regulation after buprenorphine binding. This study shows that buprenorphine is a partial agonist at MORs. The partial agonist activity of buprenorphine decreased the current induced by more potent agonists, including $[\mathrm{Met}]^{5}$ enkephalin (ME) and etorphine. Furthermore, pretreatment with buprenorphine eliminated the desensitization induced by each of these agonists. Treatment with buprenorphine also inhibited subsequent ME-induced MOR internalization, which makes it different from the effects of an irreversible antagonist, $\beta$-chlornaltrexamine ( $\beta$-CNA). These results indicate that buprenorphine is unique among opiates and illustrates the diversity of MOR signaling and regulation.

\section{Materials and Methods}

Tissue preparation and recording. Adult (150-250 g) male Sprague Dawley rats (Charles River Laboratories) were used for all experiments. Details of the method of slice preparation and recording have been published previously (Virk and Williams, 2008). Briefly, rats were anesthetized with halothane and killed. The brain was dissected, blocked, and mounted in a vibratome chamber to cut horizontal slices $(260 \mu \mathrm{m}$ thick) containing the LC. Slices were stored at $35^{\circ} \mathrm{C}$ in an artificial CSF (aCSF) containing the following (in $\mathrm{mm}$ ): $126 \mathrm{NaCl}, 2.5 \mathrm{KCl}, 2.5 \mathrm{CaCl}_{2}$, $1.2 \mathrm{MgCl}_{2}, 1.2 \mathrm{NaH}_{2} \mathrm{PO}_{4}, 21.4 \mathrm{NaHCO}_{3}$, and $11 \mathrm{D}$-glucose (while being continuously equilibrated with $95 \% \mathrm{O}_{2} / 5 \% \mathrm{CO}_{2}$ ). Slices were incubated for a minimum of $1 \mathrm{~h}$ to remove residual drug from the tissue. Slices were 
hemisected, transferred to the recording chamber $(0.5 \mathrm{ml})$, and superfused with aCSF $\left(35^{\circ} \mathrm{C}\right.$ at $\left.1.5 \mathrm{ml} / \mathrm{min}\right)$. Whole-cell recordings were made from LC neurons with an Axopatch 200B amplifier (Molecular Devices) in the voltage-clamp mode $(-55 \mathrm{mV})$. Pipettes $(1.7-2.1 \mathrm{M} \Omega)$ were filled with an internal solution containing the following (in $\mathrm{mM}$ ): 115 methyl potassium sulfate, $20 \mathrm{NaCl}, 1.5 \mathrm{MgCl}_{2}, 10 \mathrm{HEPES}, 10$ BAPTA, $2 \mathrm{Mg}$-ATP, $0.5 \mathrm{Na}-\mathrm{GTP}$, and 10 phosphocreatine, pH 7.3. Data were collected with PowerLab (Chart version 4.2.3) and sampled at $100 \mathrm{~Hz}$. Analysis was performed with Prism and Kaleidagraph software. Values are presented as arithmetic mean \pm SEM. One-way ANOVA followed by Dunnett's or Tukey's multiple comparison test were performed. Results in which $p<$ 0.05 were considered significant.

Two-photon microscopy and Flag MOR transgenic mice. A transgenic (Tg) mouse that expressed an extracellular Flag epitope on MOR in LC cells was used as described previously (Arttamangkul et al., 2008). All data were collected from hemizygous FlagMOR-Tg/+ mice. Brain slices $(200-220 \mu \mathrm{m})$ from the transgenic mouse were prepared as those described for electrophysiological experiments. Slices were incubated in a solution containing M1 antibody (Sigma) conjugated with Alexa594 (10 $\mu \mathrm{g} / \mathrm{ml}, 45-60 \mathrm{~min}$; Invitrogen). The tissue was visualized with an upright microscope (Olympus) equipped with a custom-built two-photon apparatus. Data were acquired and collected using Scan Image Software (Pologruto et al., 2003). A z-series was collected at $1 \mu \mathrm{m}$ intervals for 15 $\mu \mathrm{m}$. Drugs were applied by perfusion.

Drugs. All drugs were applied by bath superfusion. Drugs included the following: $\left[\mathrm{Met}^{5}\right]$ enkephalin (Sigma), bestatin (Sigma), thiorphan (Sigma), buprenorphine [National Institute on Drug Abuse (NIDA) Neuroscience Center], orphanin FQ/nociception (OFQ/N) (Sigma), $\beta$-chlornaltrexamine (Sigma), UK14304 [5-bromo-6-(2-imidazolin-2ylamino)-quinoxaline] (Sigma), and yohimbine (Sigma). UK14304 was dissolved in dimethylsulfoxide. Thiorphan was dissolved in ethanol. The maximum concentration used in the superfusion solution was $0.01 \%$ (DMSO) and $0.0001 \%$ ethanol. All other compounds were dissolved in water.

Protocols. Desensitization and recovery from desensitization were measured as described previously (Virk and Williams, 2008). Desensitization was defined by two measurements: (1) the depression in G-protein-gated inwardly rectifying $\mathrm{K}^{+}$channel (GIRK) current during a continuous $10 \mathrm{~min}$ treatment with a saturating concentration of $\mathrm{ME}$ $(30 \mu \mathrm{M})$ and (2) the depression of the current induced by ME (300 nM, $\left.\mathrm{EC}_{50}\right) 5 \mathrm{~min}$ after treatment with the saturating concentration. Recovery from desensitization was measured by repeated applications of ME (300 $\mathrm{nM}, \mathrm{EC}_{50}$ ) at $10 \mathrm{~min}$ intervals for $45 \mathrm{~min}$.

Drug treatment. Rats were implanted with osmotic minipumps (2ML1; Alzet) to deliver buprenorphine (NIDA Neuroscience Center) or carrier (control). The minipumps have a $2 \mathrm{ml}$ reservoir and deliver their contents for $7 \mathrm{~d}$ at the rate of $10 \mu \mathrm{l} / \mathrm{h}$. Pumps were filled with the required concentration of drug, dissolved in water, based on the weight of the rat and the desired dosing parameter (buprenorphine at 1,5 , and 10 $\left.\mathrm{mg} \cdot \mathrm{kg}^{-1} \cdot \mathrm{d}^{-1}\right)$. Buprenorphine was dissolved in $40 \%$ dimethylsulfoxide, and water constituted the balance. Rats were anesthetized with isoflurane, and an incision was made in the midscapular region to insert the pump subcutaneously. Rats were returned to their housing facility during recovery. Experiments were performed on day 6 or 7 after minipump implantation. Control animals consisted of naive animals and those implanted with vehicle-filled pumps.

Drug concentration analysis. All brain and plasma samples were analyzed at the University of Utah, Center for Human Toxicology under the supervision of Dr. Roger Foltz in conjunction with NIDA. Plasma and whole brain samples were obtained for drug (buprenorphine) concentration analysis at the time of brain slice preparation. After halothane anesthesia, $3 \mathrm{ml}$ of whole blood was obtained via cardiac puncture with a heparinized syringe. Blood was centrifuged, and plasma was collected. Brain tissue removed after blocking the LC was collected and homogenized in water. Samples were frozen at $-20^{\circ} \mathrm{C}$ and shipped to the University of Utah, Center for Human Toxicology for analysis. Samples were analyzed by liquid chromatography/tandem mass spectrometry using electrospray ionization and selected reaction monitoring. The limit of detection was $0.2-20 \mathrm{ng} / \mathrm{ml}$. Plasma samples contained 5.2, 27.7, and 58.1

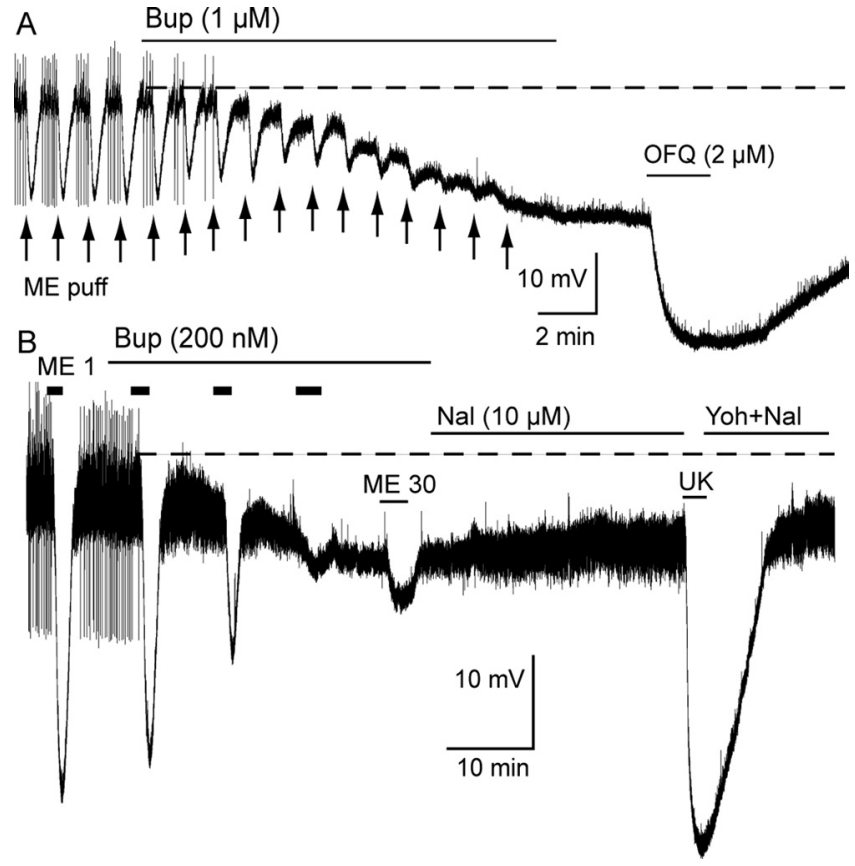

Figure 1. Buprenorphine hyperpolarized LC neurons and blocked the ME-induced hyperpolarization. Voltage recording made with intracellular electrodes. $A$, Buprenorphine (Bup; $1 \mu \mathrm{M}$ ) was applied for 15 min and caused a sustained hyperpolarization. Pressure ejection of ME (ME puff, arrows) caused a transient reproducible inhibition in spontaneous firing and hyperpolarization that was blocked by the application of buprenorphine. Application of orphanin FQ/ nociception (OFO) resulted in an additional hyperpolarization. $\boldsymbol{B}, \mathrm{ME}(1 \mu \mathrm{M}, 2 \mathrm{~min})$ caused an inhibition of spontaneous firing and a hyperpolarization of $\sim 25 \mathrm{mV}$. Buprenorphine ( $200 \mathrm{~nm}$ ) caused a hyperpolarization over a period of $25 \mathrm{~min}$. The hyperpolarization induced by $\mathrm{ME}(1 \mu \mathrm{m})$ was decreased by buprenorphine, and, after 25 min, application of ME (30 $\mu \mathrm{m})$ caused only a small hyperpolarization. Naloxone (Nal; $10 \mu \mathrm{m}$ for $25 \mathrm{~min}$ ) had little effect on the membrane potential. UK14304 (UK, $3 \mu \mathrm{m}$ ) caused a hyperpolarization of $\sim 35 \mathrm{mV}$. Yoh, Yohimbine.

$\mathrm{ng} / \mathrm{ml}$ for the three doses of buprenorphine (1, 5, and 10 $\mathrm{mg} \cdot \mathrm{kg}^{-1} \cdot \mathrm{d}^{-1}$ ) and brain samples contained 12.2, 29.1, and $64.5 \mathrm{ng} / \mathrm{ml}$ for the three doses. Thus, the osmotic minipump delivered buprenorphine efficiently and predictably.

\section{Results}

\section{Buprenorphine is a partial agonist}

Intracellular recordings were used to determine the acute action of buprenorphine. This recording technique provides a stable and sensitive assay necessary to identify the slow actions of buprenorphine. When applied at a saturating concentration, buprenorphine ( $1 \mu \mathrm{M}, 15 \mathrm{~min}$ ) caused a hyperpolarization (14.5 \pm $1.7 \mathrm{mV} ; n=8$ ) and blocked the transient hyperpolarization induced by pressure ejection-applied ME (Fig. 1, arrows). Application of a lower concentration of buprenorphine (200 nM) induced a hyperpolarization of $6.4 \pm 1.4 \mathrm{mV}$ after $35 \mathrm{~min}$ (Fig. $1 B$ ) $(n=4)$. The hyperpolarization induced by superfusion of ME ( 1 $\mu \mathrm{M})$ was decreased to $91.5 \pm 3.2 \%$ of control within $5 \mathrm{~min}$ of buprenorphine ( $200 \mathrm{nM}$ ) application and to $12.3 \pm 4.2 \%$ of control after $25 \mathrm{~min}$. The buprenorphine-induced hyperpolarization was not reversed by naloxone $(10 \mu \mathrm{M})$ even after $30 \mathrm{~min}$ application and did not affect the hyperpolarization induced by the $\alpha 2$ adrenoceptor agonist UK14304 (3 $\mu \mathrm{M})$ (Fig. $1 B$ ) or the ORL-1 agonist orphanin FQ/nociception $(2 \mu \mathrm{M})$ (Fig. $1 A$ ). Both these receptors are coupled to the same GIRK conductance, suggesting that buprenorphine $(1 \mu \mathrm{M})$ did not block the GIRK conductance directly. These results are consistent with occupation of receptors by a partial agonist that binds with high affinity.

Examination of the acute action of buprenorphine by super- 


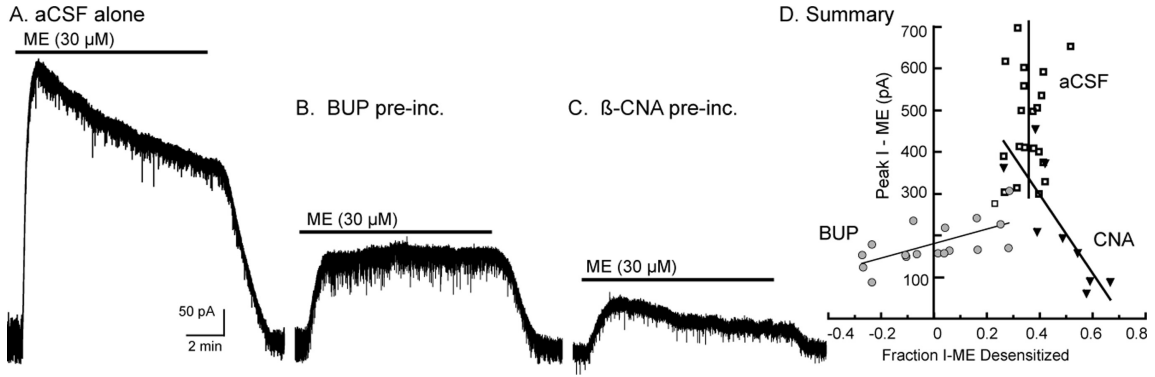

Figure 2. Buprenorphine limits ME-induced desensitization. Voltage-clamp recordings made with whole-cell electrodes. $\boldsymbol{A}, \mathrm{A}$ control experiment using an untreated slice. ME $(30 \mu \mathrm{m})$ caused a large outward current that declined during the 10 min application period. $\boldsymbol{B}$, An experiment taken from a slice that was preincubated with buprenorphine (Bup; $5 \mathrm{~nm}, 1 \mathrm{~h}) . \mathrm{ME}(30 \mu \mathrm{m})$ caused a small outward current that did not desensitize during the 10 min application. $\boldsymbol{C}$, An experiment using a slice that was preincubated with $\beta$-CNA $(20 \mathrm{~nm}, 1 \mathrm{~h})$. ME $(30 \mu \mathrm{m})$ caused a small outward current that desensitized during the 10 min application period. $D$, Summary of results, plotting the peak amplitude of the current induced by ME (30 $\mu \mathrm{m}$ ) against the amount of desensitization (the change in current from the peak to the end of the $10 \mathrm{~min}$ application divided by the peak current). The open boxes (vertical line at 35\%) indicate experiments done in control slices $(\boldsymbol{A})$. The amount of desensitization was independent of the initia amplitude of current induced by ME. The gray circles (positive sloping line) are experiments done after buprenorphine $(\boldsymbol{B})$. In this case, when the current induced by ME was larger, the amount of desensitization was greater. When the ME currents were smaller than $150 \mathrm{pA}$, the desensitization was eliminated. Filled triangles (negative sloping line) are experiments done after $\beta$-CNA (C). In this case, as the current induced by ME decreased, the amount of desensitization was increased.

fusion of concentrations $<200 \mathrm{~nm}$ was not possible because of the slow onset of action. To determine whether buprenorphine was occupying receptors or capable of signaling at lower concentrations, slices were preincubated in buprenorphine $(5 \mathrm{nM}, 1 \mathrm{~h}$ ) before the beginning of the experiment. A sustained hyperpolarization was observed in recordings made from slices preincubated in buprenorphine ( $5 \mathrm{~nm}, 1 \mathrm{~h}$ ) (supplemental Fig. S1C, available at www.jneurosci.org as supplemental material). Although it was not possible to determine the amplitude of the hyperpolarization induced by this treatment protocol, the spontaneous firing that is characteristic of LC neurons was eliminated, and the membrane potential was approximately $-65 \mathrm{mV}$, which is $10 \mathrm{mV}$ more hyperpolarized than cells in untreated slices. This observation demonstrated that preincubation with buprenorphine $(5 \mathrm{~nm}, 1 \mathrm{~h})$ resulted in a sustained hyperpolarization that was smaller than that induced by buprenorphine $(1 \mu \mathrm{M})$. In slices preincubated with buprenorphine ( $5 \mathrm{nM}, 1 \mathrm{~h}$ ), application of $\mathrm{ME}$ $(30 \mu \mathrm{M})$ caused an additional hyperpolarization $(14 \pm 1.1 \mathrm{mV}$; $n=7$ ) (supplemental Fig. S1, available at www.jneurosci.org as supplemental material) that was less than that induced by the acute application of $\mathrm{ME}(34.5 \pm 1.5 \mathrm{mV} ; n=5)$ in control slices. Thus, pretreatment with buprenorphine ( $5 \mathrm{nM}, 1 \mathrm{~h})$ occupied a fraction of MORs without complete saturation.

The slow dissociation rate of buprenorphine from receptors was indicated by the inability of naloxone $(10 \mu \mathrm{M}, 30 \mathrm{~min})$ to reverse the hyperpolarization induced by buprenorphine (Fig. $1 B)$. Although naloxone did not reverse the buprenorphineinduced hyperpolarization, pretreatment of slices with the irreversible opioid antagonist $\beta$-CNA ( $1 \mu \mathrm{M}, 10 \mathrm{~min})$ completely blocked the hyperpolarization induced by a high concentration of buprenorphine ( $1 \mu \mathrm{M}, 15 \mathrm{~min}, 0.8 \mathrm{mV} ; n=4)$. Together, the results suggest that the hyperpolarization induced by buprenorphine $(\leq 1 \mu \mathrm{M})$ was mediated by the activation of MORs. The slow activation of the buprenorphine-induced hyperpolarization likely resulted from the slow binding kinetics, low efficacy, and the necessity for a high degree of receptor occupancy to cause a change in membrane potential.

\section{Buprenorphine eliminated MOR desensitization}

Using whole-cell recording, buprenorphine did not cause a detectable outward current, even when applied at a saturating con- centration $(1 \mu \mathrm{M})$. It did, however, decrease the amplitude of the outward current induced by ME. Buprenorphine (100 nM) applied for a period of 20-30 min resulted in complete inhibition of the current induced by ME (300 nM, 2 min; $n=3)$, and the current induced by $\operatorname{ME}(30$ $\mu \mathrm{M})$ was reduced by $>70 \%$. In addition, the current induced by ME $(30 \mu \mathrm{M})$ immediately after preincubation with buprenorphine ( $5 \mathrm{~nm}, 1 \mathrm{~h}$ ) was reduced to $43 \pm 5 \%$ of the current induced by the $\alpha 2$ adrenoceptor agonist UK14304 ( $3 \mu \mathrm{M}, n=6)$ compared with $135 \pm 6 \%(n=20)$ in untreated slices. When slices were washed for $4 \mathrm{~h}$ after buprenorphine treatment, the current induced by ME remained at $48 \pm$ $3 \%$ of that caused by UK14304 ( $3 \mu \mathrm{M} ; n=$ $6)$. Thus, preincubation with buprenorphine resulted in a stable, long-lasting inhibition of the current induced by ME that was consistent with slow dissociation kinetics.

In control slices, $\mathrm{ME}(30 \mu \mathrm{M})$ caused a peak current of $461 \pm$ $28 \mathrm{pA}$ that desensitized by $35 \pm 1 \%$ over a $10 \mathrm{~min}$ application (Fig. 2A). The peak current induced by $\mathrm{ME}(30 \mu \mathrm{M})$ varied among individual cells (276-698 pA), but the amount of desensitization after application of $\mathrm{ME}(30 \mu \mathrm{M}, 10 \mathrm{~min})$ was $35 \pm 1 \%$ and did not vary with the amplitude of the initial current (Fig. $2 D$, vertical line, $95 \%$ confidence limits, $23-47 \%$ ). The decline in the ME-induced current was the same after a 5 and 15 min application, indicating that, after $\sim 5 \mathrm{~min}$, the rate of desensitization and recovery from desensitization had reached equilibrium (Dang and Williams, 2004). After preincubation with buprenorphine $(5 \mathrm{nM}, 1 \mathrm{~h})$, the peak $\mathrm{ME}(30 \mu \mathrm{M})$ current was reduced to $175 \pm 13 \mathrm{pA}(n=18)$ (Fig. $2 B)$. In slices preincubated in buprenorphine ( $5 \mathrm{nM}, 1 \mathrm{~h}$ ), $\mathrm{ME}(30 \mu \mathrm{M}, 10 \mathrm{~min})$ desensitization was considerably attenuated but varied as a function of the peak current (fraction desensitization, -25 to $30 \%$ ). When the initial current induced by ME was $<150 \mathrm{pA}$, the current increased in amplitude during the $10 \mathrm{~min}$ application (Fig. $2 \mathrm{D}$, circles, positively sloping line). Thus, as more receptors were occupied by buprenorphine, the amount of ME-induced desensitization decreased.

It was possible that buprenorphine blocked desensitization by decreasing the number of receptors as a result of the high affinity and slow dissociation rate. To test this, receptors were eliminated by preincubation of slices with the irreversible MOR antagonist $\beta$-CNA (5-40 nM, $1 \mathrm{~h}$ ). Multiple concentrations of $\beta$-CNA were tested to obtain a range of currents induced by ME that could be compared with the results obtained with buprenorphine. Regardless of the $\beta$-CNA concentration used, the peak current induced by $\mathrm{ME}(30 \mu \mathrm{M}, 10 \mathrm{~min})$ desensitized (Fig. 2C). Furthermore, when the peak current induced by ME was 150 pA or less, the amount of desensitization was greater (Fig. 2D, triangles, negatively sloping line) than in untreated controls. Thus, removal of receptors with the irreversible antagonist $\beta$-CNA increased the extent of ME-induced desensitization, whereas incubation with buprenorphine had the opposite effect.

The action of buprenorphine to block desensitization was further tested by using etorphine. Etorphine was chosen because it is a high-affinity agonist that is structurally similar to buprenorphine. In control experiments, etorphine caused an outward cur- 
rent that declined by $35 \pm 1.7 \%$ of the peak after $10 \mathrm{~min}$, which was similar to that caused by ME (Fig. 3A) $(n=6)$. After incubation of slices in buprenorphine $(5 \mathrm{nM}$, $1 \mathrm{~h}$ ), the peak current induced by etorphine was decreased from $117 \pm 6.0 \%$ $(n=6)$ to $57 \pm 7 \%(n=9)$ of the current induced by the $\alpha 2$ adrenoceptor agonist UK14304 (3 $\mu \mathrm{M})$. Acute desensitization induced by etorphine ( $1 \mu \mathrm{M}, 10 \mathrm{~min})$ was also eliminated by incubating slices with buprenorphine (Fig. 3B). After $10 \mathrm{~min}$, the etorphine-induced current was $100 \pm 4 \%$ of the peak value $(n=9)$. The results indicate that the desensitization induced by both $\mathrm{ME}$ and etorphine was blocked by pretreatment with buprenorphine.

The elimination of MOR desensitization is unique to buprenorphine

Previous experiments demonstrated that desensitization was not blocked by pretreating slices with the irreversible antagonist $\beta$-CNA (Fig. 2). To determine whether this effect was specific to buprenorphine, ME-induced desensitization was measured after preincubation with four other agonists: etorphine, methadone, oxymorphone, and oxycodone.

\section{Etorphine}

It was possible that the high affinity and slow binding kinetics of buprenorphine alone could result in signaling that resulted in the block of desensitization and that any agonist with similar properties would have the same effect. To test this possibility, slices were preincubated with the high-affinity agonist etorphine. Slices were incubated in a low concentration of etorphine ( $2 \mathrm{nM}, 1 \mathrm{~h}$ ) before testing for desensitization induced by ME (Fig. 4A). After incubation with etorphine, desensitization induced by $\mathrm{ME}(30 \mu \mathrm{M}, 10 \mathrm{~min})$ was examined. The peak current induced by $\mathrm{ME}(30 \mu \mathrm{M})$ measured $149 \pm 14 \mathrm{pA}$ $(n=7)$ and declined to $79 \pm 14 \mathrm{pA}$ after 10 min (desensitized by $49 \pm 9 \%$ ). After washing ME, the opioid antagonist, naloxone $(1 \mu \mathrm{M})$ was applied to determine whether etorphine remained in the slice. Naloxone caused an inward current of $-151 \pm 42 \mathrm{pA}(n=7)$. Thus, etorphine did not wash out of the brain slice as has been demonstrated previously (Virk and Williams, 2008). Etorphine did not eliminate ME-induced desensitization and is therefore distinct from buprenorphine.

\section{Methadone}

Methadone is a partial agonist that causes both desensitization (Virk and Williams, 2008) and internalization (Arttamangkul et al., 2008). Incubation of slices with methadone ( $1 \mu \mathrm{M}, 1 \mathrm{~h})$ resulted in a sustained outward current that was detected by the application of naloxone $(1 \mu \mathrm{M})$ at the end of the experiment (Fig. $4 B)(-158 \pm 22 \mathrm{pA} ; n=3)$. Application of $\mathrm{ME}(30 \mu \mathrm{M})$ resulted in a peak current that desensitized (by $47 \pm 11 \%$; $n=3$ ). Thus, Yohimbine.

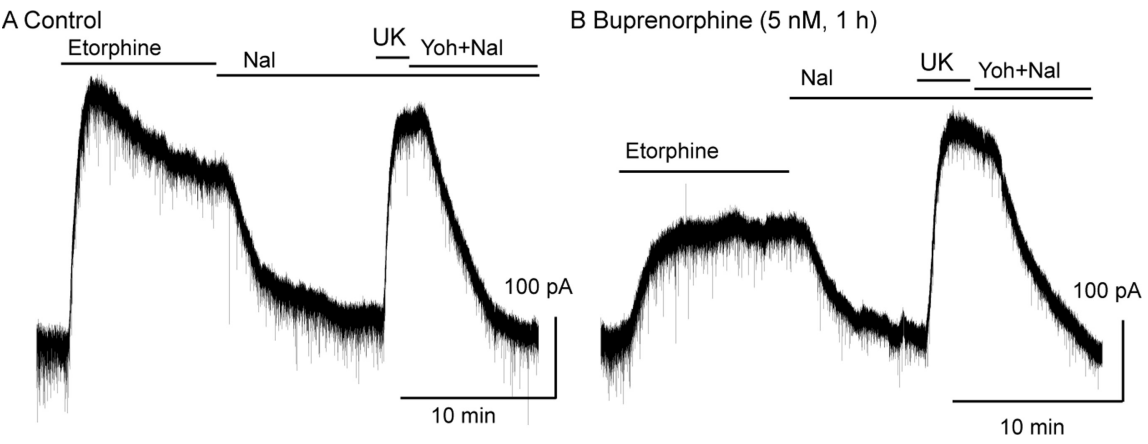

Figure 3. Buprenorphine blocked desensitization induced by etorphine. $A, A$ control experiment showing the desensitization induced by etorphine $(1 \mu \mathrm{M})$, the reversal of the current induced by naloxone (Nal; $1 \mu \mathrm{M})$, and the current induced by UK14304 (UK; $3 \mu \mathrm{m}$ ). $\boldsymbol{B}$, An experiment done in a slice that was incubated in buprenorphine ( $5 \mathrm{~nm}, 1 \mathrm{~h}$ ). The current induced by etorphine (1 $\mu \mathrm{m})$ is significantly smaller and did not desensitize during the $10 \mathrm{~min}$ application period. Yoh, Yohimbine.
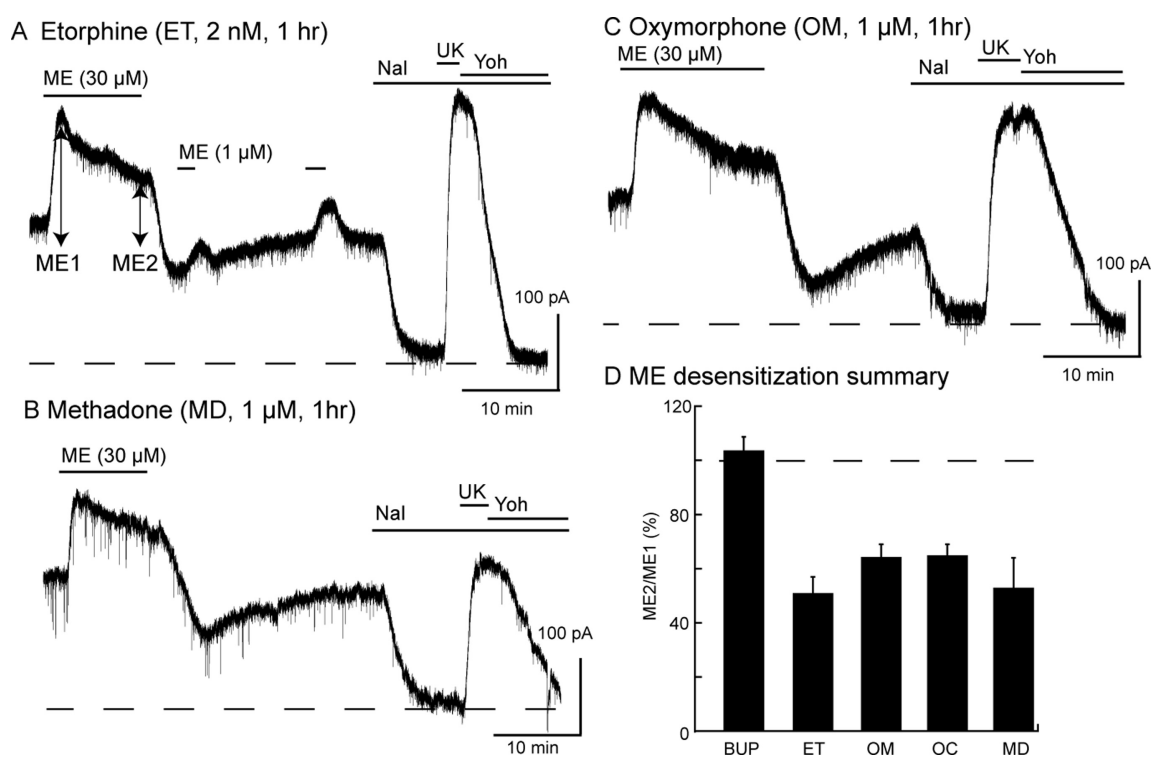

Figure 4. Incubation of slices with etorphine, oxymorphone, methadone, or oxycodone did not block ME-induced desensitization. $\boldsymbol{A}$, Sample experiment from a slice that was incubated with etorphine ( $2 \mathrm{~nm}, 1 \mathrm{~h}$ ) before recording the outward current induced by ME (30 $\mu \mathrm{M}, 10 \mathrm{~min}$ ). The ME current peaked (ME1) and declined (ME2) during the 10 min application period. (halo naloxone (Nal; $1 \mu \mathrm{m}$ ) caused an inward current, indicating the presence of etorphine in the slice. $\boldsymbol{B}$, The same experiment done with slices that were incubated with methadone $(1 \mu \mathrm{M}) \mathbf{C}$, The same experiment done with oxymorphone (1 experiment. There was a marked decrease in the ME current in all experiments except in slices incubated in buprenorphine. Yoh,

treatment of slices with methadone had no obvious effect on acute MOR desensitization.

\section{Oxymorphone}

Pretreatment with oxymorphone $(1 \mu \mathrm{M})$ resulted in a sustained outward current $(85 \pm 23 \mathrm{pA} ; n=5)$ that was reversed by naloxone $(1 \mu \mathrm{M})$ and a small decrease in the amplitude of the current induced by a saturating concentration of $\mathrm{ME}(30 \mu \mathrm{M}, 100.7 \pm$ $10.0 \%$ of the current induced by UK14304, $3 \mu \mathrm{M} ; n=7)$. In slices that were incubated in oxymorphone $(1 \mu \mathrm{M}, 1 \mathrm{~h} ; n=9)$ (Fig. $4 C$ ), application of $\mathrm{ME}(30 \mu \mathrm{M}, 10 \mathrm{~min})$ caused an outward current that desensitized by $35.8 \pm 5.4 \%$. Thus, ME-induced desensitization after preincubation with oxymorphone remained intact.

\section{Oxycodone}

Oxycodone applied at a saturating concentration $(15 \mu \mathrm{M})$ does not induce desensitization (Virk and Williams, 2008). Preincu- 


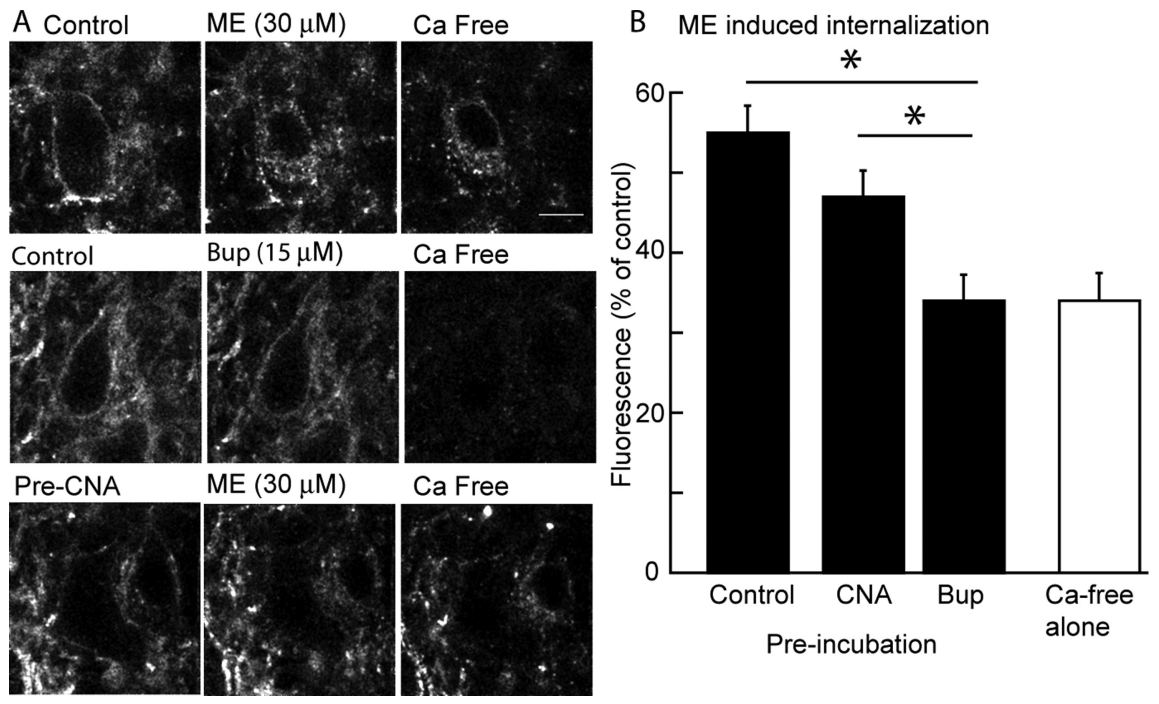

Figure 5. Buprenorphine does not cause receptor internalization and blocked the internalization induced by ME. $\boldsymbol{A}$, Images of cells in three experiments. Left, Images taken at the beginning of the experiment after incubating slices with M1 anti-Flag antibody without drugs (top 2 images) or $\beta$-CNA (10 nm, $1 \mathrm{~h}$; bottom image). The top three images are a control experiment demonstrating the internalization of receptor evoked by $\mathrm{ME}(30 \mu \mathrm{M}, 15 \mathrm{~min})$. The fluorescence image on the right is only internalized receptors after treatment of the slice with a calcium-free solution to strip antibody bound to extracellular surface. Middle images show that buprenorphine $(15 \mu \mathrm{m})$ did not induce any internalization. The bottom images show that treatment of slices with a low concentration of $\beta$-CNA reduced but did not abolish the ME-induced receptor internalization. Scale bar, $10 \mu \mathrm{m}$. $\boldsymbol{B}$, Summarized results from several experiments showing the amount of internalization (fluorescence as a percentage of the control) induced by ME in control, after treatment of slices with $\beta$-CNA (10 nm, $1 \mathrm{~h}$ ) or buprenorphine (Bup; $5 \mathrm{~nm}, 1 \mathrm{~h}$ ). The open bar is the background fluorescence measured after treatment of the slices with calcium-free solution without application of any drug. ${ }^{*} p<0.05$

bation of slices in oxycodone $(1 \mu \mathrm{M}, 1 \mathrm{~h})$ had no affect on $\mathrm{ME}(30$ $\mu \mathrm{M})$-induced desensitization. The current induced by ME decreased by $35 \pm 4 \%$ during a $10 \mathrm{~min}$ application of ME (Fig. $4 D$ ).

Thus, unlike the results obtained with buprenorphine, desensitization induced by ME remained completely intact after treatment of slices with each of these other agonists.

\section{Buprenorphine treatment did not block desensitization of ORL-1 receptors}

To determine whether buprenorphine blocked desensitization of other G-protein-coupled receptors that are expressed on LC neurons, slices were incubated with buprenorphine $(5 \mathrm{nM}, 1 \mathrm{~h})$ before the ORL-1 receptor agonist OFQ/N was tested. Application of $\mathrm{OFQ} / \mathrm{N}(2 \mu \mathrm{M}, 10 \mathrm{~min})$ caused a peak outward current of $257 \pm$ $22 \mathrm{pA}(n=11)$ that declined by $34 \pm 2.9 \%$ (data not shown). Thus, ORL-1 receptors, which activate the same GIRK conductance as MORs, desensitized in buprenorphine-incubated slices. This demonstrates that the block of opioid receptor-dependent desensitization did not generalize to other receptors.

\section{Buprenorphine eliminated MOR internalization}

It has been established that buprenorphine does not induce receptor internalization in several preparations (Zaki et al., 2000). A transgenic mouse that expressed an epitope (Flag)-tagged MOR in tyrosine hydroxylase-containing neurons was used to examine the change in receptor trafficking induced by buprenorphine. In these experiments, slices were incubated in a solution containing the anti-Flag antibody (M1) that was conjugated with Alexa594 for 30 min before imaging and then treated with ME (30 $\mu \mathrm{M})$ or buprenorphine $(15 \mu \mathrm{M})$ or untreated for $15 \mathrm{~min}$ and imaged before treatment of the slice with a calcium-free solution (+EGTA, $0.5 \mathrm{~mm}$ ). The calcium-free solution resulted in the displacement of the antibody from the receptor in the extracellular space such that the remaining fluorescence resulted only from internalized MOR. Experiments in which no agonist was applied before treatment with the calcium-free solution were used to control for autofluorescence (Fig. $5 B$, calcium-free alone). When a supersaturating concentration of buprenorphine $(15 \mu \mathrm{M})$ was applied to the slice, internalization was not induced (Fig. 5A). In contrast, $\mathrm{ME}(30 \mu \mathrm{M})$ resulted in robust internalization, as reported previously (Arttamangkul et al., 2008).

Slices were then preincubated with buprenorphine ( $5 \mathrm{nM}, 1 \mathrm{~h}$ ) before the application of a saturating concentration of $\mathrm{ME}$ (30 $\mu \mathrm{M}, 15 \mathrm{~min}$ ). In these experiments, $\mathrm{ME}$ did not induce any internalization above baseline (Fig. $5 B$ ). It was possible that the sensitivity of the assay was too low to detect a small number of internalized receptors. To address this possibility, slices were pretreated with $\beta$-CNA (10 nM, $1 \mathrm{~h}$ ), to reduce the receptor number before measuring $\mathrm{ME}$-induced internalization. In slices preincubated in $\beta$-CNA, ME $(30 \mu \mathrm{M}$, $15 \mathrm{~min}$ ) caused a detectable amount of internalized receptors that, as expected, was less than that found in control (Fig. 5A,B). Thus, it was possible to observe receptor internalization under conditions in which the number of receptors was depleted. These results indicate that buprenorphine alone did not induce internalization at a high concentration and a low concentration blocked both desensitization and internalization induced by ME.

\section{Chronic buprenorphine treatment}

Animals were treated with three different doses of buprenorphine $\left(1,5\right.$, and $\left.10 \mathrm{mg} \cdot \mathrm{kg}^{-1} \cdot \mathrm{d}^{-1}\right)$ for $6-7 \mathrm{~d}$ before slices were prepared. All experiments used a saturating concentration of ME (30 $\mu \mathrm{M}, 10 \mathrm{~min}$ ) to induce desensitization, followed by the application of a lower concentration to measure the extent of recovery from desensitization. The results of these experiments show that there were two effects of buprenorphine that were dose dependent: the peak current induced by $\mathrm{ME}(30 \mu \mathrm{M})$ was reduced (Fig. $6 A-C)$ and $\mathrm{ME}(30 \mu \mathrm{M} / 10 \mathrm{~min})$-induced desensitization was inhibited (Fig. $6 B, D, E$ ).

The amplitude of the ME-induced current was reduced as the dose of buprenorphine increased (Fig. 6). The current induced by ME $(30 \mu \mathrm{M})$, expressed as a percentage of current induced by UK14304 $(3 \mu \mathrm{M})$, was $136 \pm 5 \%(n=20)$ in control. Peak ME (30 $\mu \mathrm{M})$-induced currents decreased to $96 \pm 4 \%(n=6), 74 \pm 7 \%$ $(n=6)$, and $47 \pm 4 \%(n=8)$ as buprenorphine treatment increased from 1,5 , and $10 \mathrm{mg} \cdot \mathrm{kg}^{-1} \cdot \mathrm{d}^{-1}$ (Fig. 6C). This dosedependent decrease in current amplitude suggests that the percentage of buprenorphine occupied MORs increased as the treatment dose increased.

In untreated animals, the $\mathrm{ME}(30 \mu \mathrm{M})$ current desensitized by $35 \pm 2 \%$ during a $10 \mathrm{~min}$ application. Desensitization after 10 min was $45 \pm 3,24 \pm 5$, and $10 \pm 6 \%$ in slices taken from animals that received 1,5 , and $10 \mathrm{mg} \cdot \mathrm{kg}^{-1} \cdot \mathrm{d}^{-1}$ buprenorphine, respectively (Fig. 6D). Thus, desensitization was inhibited in animals 
treated with buprenorphine in a dosedependent manner. The decline in current induced by a low concentration of ME after desensitization was also dependent on the dose. In slices taken from animals treated with $1 \mathrm{mg} \cdot \mathrm{kg}^{-1} \cdot \mathrm{d}^{-1}$, the desensitization was not different from slices taken from untreated animals. With higher doses, the amount of desensitization was reduced and recovery from the reduced desensitization was more complete (Fig. 6E).

\section{Discussion}

The results indicate that buprenorphine is a weak partial agonist that has extremely slow dissociation kinetics at MORs. The greater sensitivity and stability of intracellular recording allowed the measurement of an acute hyperpolarization induced by buprenorphine. Once bound, buprenorphine did not dissociate during the time course of the recordings. Although the outward current induced by high-affinity agonists such as etorphine and fentanyl was reversed by naloxone, it was not possible to reverse the buprenorphineinduced hyperpolarization. After incubation with buprenorphine ( $5 \mathrm{nM}, 1 \mathrm{~h})$, a large fraction of the receptor population was occupied as determined by the reduction in the peak current caused by ME. In addition, receptor desensitization and internalization induced by ME were eliminated. Incubation with a series of opioid agonists, partial agonists, and antagonists also decreased the amplitude of the current induced by ME but did not block desensitization. Thus, buprenorphine is unique among opioids in that it is a weak, partial agonist that blocked the desensitization and internalization induced by ME.

\section{Mechanisms of buprenorphine action}

The cellular actions of buprenorphine have been examined by measuring multiple effectors. In virtually every assay, it has been shown to be a partial MOR agonist. It binds with nanomolar affinity to MORs, stimulates GTP- $\gamma$-S binding, inhibits adenylyl cyclase, activates mitogen-activated protein (MAP) kinase (Zaki et al., 2000; Lutfy et al., 2003; Clark et al., 2008), and, as shown in the present study, activates GIRK conductance. The low intrinsic efficacy of buprenorphine results in the slow turnover of activated G-proteins. Rapid GTP hydrolysis of the $\mathrm{G} \alpha_{\mathrm{i}}$ subunit attributable to the presence of regulator of G-protein signaling proteins is thought to further decrease the efficacy of buprenorphine. These characteristics are presumed to contribute to the limited ability of buprenorphine to activate various effectors (Clark et al., 2008). Buprenorphine did not induce internalization and competitively blocked etorphine-induced internalization in cell lines (Zaki et al., 2000). Finally, a G-proteinindependent, pertussis toxin-insensitive, increase in cell surface expression induced by buprenorphine, similar to that caused by naloxone, has been demonstrated in cell lines (Zaki et al., 2000). Buprenorphine therefore has pharmacological properties that are a mix of a weak partial agonist and an antagonist.

The block of desensitization shown here was only observed under conditions in which the number of available receptors was dramatically depressed. Desensitization with a saturating concentration of $\mathrm{ME}(30 \mu \mathrm{M}, 5 \mathrm{~min})$ has been shown to decrease the MOR reserve by $\sim 90 \%$ (Osborne and Williams, 1995). Buprenorphine $(5 \mathrm{nM}, 1 \mathrm{~h})$ pretreatment decreased the peak current induced by $\mathrm{ME}(30 \mu \mathrm{M})$ to a greater extent than desensitizing the receptors with a $10 \mathrm{~min}$ application of $\mathrm{ME}(30 \mu \mathrm{M})$. It follows that buprenorphine caused a more dramatic decrease in receptor reserve than ME-induced desensitization. In buprenorphinetreated slices, the block of ME-induced desensitization was variable but occurred as a function of the initial peak ME current. When the peak current was $>150 \mathrm{pA}$, some desensitization occurred. However, when the peak current was $<150 \mathrm{pA}$, the MEinduced current increased over the course of a 10 min application. Pretreatment with other high-affinity agonists also decreased the peak ME-induced current but had no effect on desensitization. Moreover, in contrast to the results obtained with buprenorphine, when $\beta$-CNA pretreatment was used to reduce receptor reserve, ME-induced desensitization was facilitated (Fig. 2D). This result is consistent with experiments in HEK293 cells showing that reducing MOR reserve with the irreversible antagonist $\beta$-CNA increased etorphine-induced desensitization (Law et al., 2000). Thus, unlike all other ligands tested, buprenorphine reduced the ability of ME to activate the potassium conductance, induce internalization, and cause desensitization.

It is unlikely that buprenorphine caused desensitization of MORs. Using intracellular recordings, a sustained hyperpolarization was observed after application of high $(1 \mu \mathrm{M})$ and low concentrations (200 and $5 \mathrm{~nm}$ ). As was found with other low efficacy agonists, buprenorphine did not result in receptor phosphorylation at saturating concentrations (Yu et al., 1997). Although bu- 
prenorphine is known to activate MAP kinase, the minimum effective concentration was $>30 \mathrm{~nm}$ (Lutfy et al., 2003). In the present study, buprenorphine ( $5 \mathrm{~nm}$ ) resulted in a sustained and stable hyperpolarization.

\section{Buprenorphine acted on opioid receptors}

Buprenorphine activates the ORL-1 receptor to limit antinociception, motor stimulation, and conditioned place preference mediated by MORs (Lutfy et al., 2003; Marquez et al., 2007; Marquez et al., 2008). The ORL-1 receptor knock-out animal was more sensitive to buprenorphine, whereas the MOR knock-out animal was insensitive to the rewarding and antinociceptive actions of buprenorphine (Lutfy et al., 2003; Marquez et al., 2007, 2008). The role of the ORL-1 receptor in mediating the actions of buprenorphine in vivo remains to be completely characterized (Yamamoto et al., 2006; Spagnolo et al., 2008). The affinity of buprenorphine for the ORL-1 receptor is 50-fold lower than that for MOR (Marquez et al., 2008; Spagnolo et al., 2008). Experiments presented here show that the hyperpolarization induced by saturating concentrations of buprenorphine $(1 \mu \mathrm{M})$ was completely blocked by the irreversible MOR antagonist $\beta$-CNA, and this concentration far exceeded the primary experimental concentration of $5 \mathrm{nM}$. Additionally, buprenorphine had no effect on the peak hyperpolarization induced by OFQ/N. Together, the results of the present study do not appear to involve the activation of the ORL-1 receptor.

\section{Chronic treatment}

Chronic treatment with buprenorphine resulted in a concentration-dependent inhibition of the current induced by ME that was identical to that observed with acute application to brain slices. Both peak ME current and desensitization were decreased in a dose-dependent manner. Thus, the results indicate that there were few if any adaptive changes measured at the single-cell level that resulted from the chronic treatment and may be a therapeutic advantage.

The doses used in this study $\left(1,5\right.$, and $\left.10 \mathrm{mg} \cdot \mathrm{kg}^{-1} \cdot \mathrm{d}^{-1}\right)$ are in the range of those used to achieve maximal analgesia. A single subcutaneous dose of $2.5,10$, and $40 \mathrm{mg} / \mathrm{kg}$ induced maximal analgesia within $60 \mathrm{~min}$, using the tail immersion assay (Meert and Vermeirsch, 2005). The high affinity of buprenorphine for MOR has been viewed as a double-edged sword. Although the slow pharmacokinetics may diminish the ability to experience opiate-mediated euphoria in patients on maintenance therapy, it may also be a liability in the same population if opiate analgesia is required for pain management. The results presented here indicate that slices prepared from animals maintained on effective doses still signal acutely. There is also concern over the safety of buprenorphine because of the slow dissociation kinetics and the possibility that naloxone does not displace buprenorphine from receptors. Although naloxone was unable to displace buprenorphine over a period of 10-30 min in the present experiment, in vivo studies examining the ability of naloxone to reverse buprenorphine-induced analgesia have found that this is possible, particularly with high or repetitive doses of naloxone (Kögel et al., 2005).

\section{Conclusion}

Buprenorphine is a reasonable analgesic as well as a safe and effective alternative to methadone for opiate maintenance therapy (Johnson et al., 2000; Raisch et al., 2002; Kakko et al., 2003, 2008). Chronic buprenorphine treatment almost completely eliminated the ability of opioid abusers to subjectively detect an acute injection of morphine (Teoh et al., 1994). Thus, treatment with buprenorphine can limit relapse to opioid abuse, although it may not be effective in all individuals (Teoh et al., 1994). Moreover, there was little or no sign of adverse cardiovascular, respiratory, or temperature reactions associated with acute administration of morphine or cocaine in patients maintained on daily buprenorphine treatment (Teoh et al., 1993). This suggests that there is no increase in physiological risk for patients maintained on buprenorphine, an important consideration for a population often engaged in polydrug abuse. Treatment of animals with buprenorphine results in tolerance to opioids and supports the idea that there is an inverse correlation between efficacy and the development of tolerance (Walker and Young, 2001; Koch et al., 2005; Grecksch et al., 2006). The present study offers a cellular explanation that supports the observation that effective analgesia can be obtained in patients receiving low-dose buprenorphine maintenance therapy (Alford et al., 2006). Buprenorphine has agonist activity yet exhibits pharmacological properties that are more characteristic of an antagonist. The combined pharmacological actions distinguish it from other opioids and may have important implications for clinical utility.

\section{References}

Alford DP, Compton P, Samet JH (2006) Acute pain management for patients receiving maintenance methadone or buprenorphine therapy. Ann Intern Med 144:127-134.

Arttamangkul S, Quillinan N, Low MJ, von Zastrow M, Pintar J, Williams JT (2008) Differential activation and trafficking of mu-opioid receptors in brain slices. Mol Pharmacol 74:972-979.

Bloms-Funke P, Gillen C, Schuettler AJ, Wnendt S (2000) Agonistic effects of the opioid buprenorphine on the nociceptin/OFQ receptor. Peptides 21:1141-1146.

Clark MJ, Linderman JJ, Traynor JR (2008) Endogenous regulators of G protein signaling differentially modulate full and partial $\mu$-opioid agonisnts at adenylyl cyclase as predicted by a collision coupling model. Mol Pharmacol 73:1538-1548.

Connock M, Juarez-Garcia A, Jowett S, Frew E, Liu Z, Taylor RJ, Fry-Smith A, Day E, Lintzeris N, Roberts T, Burls A, Taylor RS (2007) Methadone and buprenorphine for the management of opioid dependence: a systematic review and economic evaluation. Health Technol Assess 11:1-171, iii-iv.

Dahan A, Yassen A, Bijl H, Romberg R, Sarton E, Teppema L, Olofsen E, Danhof M (2005) Comparison of the respiratory effects of intravenous buprenorphine and fentanyl in humans and rats. $\mathrm{Br} \mathrm{J}$ Anaesth 94:825-834.

Dahan A, Yassen A, Romberg R, Sarton E, Teppema L, Olofsen E, Danhof M (2006) Buprenorphine induces ceiling in respiratory depression but not in analgesia. Br J Anaesth 96:627-632.

Dang VC, Williams JT (2004) Chronic morphine treatment reduces recovery from opioid desensitization. J Neurosci 24:7699-7706.

Gerra G, Borella F, Zaimovic A, Moi G, Bussandri M, Bubici C, Bertacca S (2004) Buprenorphine versus methadone for opioid dependence: predictor variables for treatment outcome. Drug Alcohol Depend 75:37-45.

Grecksch G, Bartzsch K, Widera A, Becker A, Höllt V, Koch T (2006) Development of tolerance and sensitization to different opioid agonists in rats. Psychopharmacology 186:177-184.

Hayes BD, Klein-Schwartz W, Doyon S (2008) Toxicity of buprenorphine overdoses in children. Pediatrics 121:e782-e786.

Huang P, Kehner GB, Cowan A, Liu-Chen LY (2001) Comparison of pharmacological activities of buprenorphine and norbuprenorphine: norbuprenorphine is a potent opioid agonist. J Pharmacol Exp Ther 297:688-695.

Johnson RE, Chutuape MA, Strain EC, Walsh SL, Stitzer ML, Bigelow GE (2000) A comparison of levomethadyl acetate, buprenorphine, and methadone for opioid dependence. N Engl J Med 343:1290-1297.

Kajiwara M, Aoki K, Ishii K, Numata H, Matsumiya T, Oka T (1986) Agonist and antagonist actions of buprenorphine on three types of opioid receptor in isolated preparations. Jpn J Pharmacol 40:95-101.

Kakko J, Svanborg KD, Kreek MJ, Heilig M (2003) 1-year retention and social function after buprenorphine-assisted relapse prevention treat- 
ment for heroin dependence in Sweden: a randomized, placebocontrolled trial. Lancet 361:662-668.

Kakko J, Grönbladh L, Svanborg KD, von Wachenfeldt J, Rück C, Rawlings B, Nilsson LH, Heilig M (2007) A stepped care strategy using buprenorphine and methadone versus conventional methadone maintenance in heroin dependence: a randomized controlled trial. Am J Psychiatry 164:797-803.

Kakko J, Heilig M, Sarman I (2008) Buprenorphine and methadone treatment of opiate dependence during pregnancy: comparison of fetal growth and neonatal outcomes in two consecutive case series. Drug Alcohol Depend 96:69-78.

Koch T, Widera A, Bartzsch K, Schulz S, Brandenburg LO, Wundrack N, Beyer A, Grecksch G, Höllt V (2005) Receptor endocytosis counteraction the development of opioid tolerance. Mol Pharmacol 67:280-287.

Kögel B, Christoph T, Strassburger W, Friderichs E (2005) Interaction of mu-opioid receptor agonists and antagonists with the analgesic effect of buprenorphine in mice. Eur J Pain 9:599-611.

Law PY, Erickson LJ, El-Kouhen R, Dicker L, Solberg J, Wang W, Miller E, Burd AL, Loh HH (2000) Receptor density and recycling affect the rate of agonist-induced desensitization of mu-opioid receptor. Mol Pharmacol 58:388-398

Leander JD (1987) Buprenorphine has potent kappa opioid receptor antagonist activity. Neuropharmacology 26:1445-1447.

Lutfy K, Eitan S, Bryant CD, Yang YC, Saliminejad N, Walwyn W, Kieffer BL, Takeshima H, Carroll FI, Maidment NT, Evans CJ (2003) Buprenorphine-induced antinociception is mediated by $\mu$-opioid receptors and compromised by concomitant activation of opioid receptor-like receptors. J Neurosci 23:10331-10337.

Marquez P, Baliram R, Kieffer BL, Lutfy K (2007) The mu opioid receptor is involved in buprenorphine-induced locomotor stimulation and conditions place preference. Neuropharmacology 52:1336-1341.

Marquez P, Borse J, Nguyen AT, Hamid A, Lutfy K (2008) The role of the opioid receptor-like (ORL1) receptor in motor stimulatory and rewarding actions of buprenorphine and morphine. Neuroscience 155:597-602.

Meert TF, Vermeirsch HA (2005) A preclinical comparison between different opioids: antinociceptive versus adverse effects. Pharmacol Biochem Behav 80:309-326.

Osborne PB, Williams JT (1995) Characterization of acute homologous desensitization of $\mu$-opioid receptor induced currents in locus coeruleus neurons. Br J Pharmacol 115:925-932.

Pergolizzi J, Böger RH, Budd K, Dahan A, Erdine S, Hans G, Kress HG, Langford R, Likar R, Raffa RB, Sacerdote P (2008) Opioids and the management of chronic severe pain in the elderly: consensus statement of an international expert panel with focus on the six clinically most often used world health organization step III opioid (buprenorphine, fentanyl, hydromorphone, methadone, morphine oxycodone). Pain Pract 8:287-313.

Pologruto TA, Sabatini BL, Svoboda K (2003) ScanImage: flexible software for operating laser scanning microscopes. Biomed Eng Online 2:13.

Raisch DW, Fye CL, Boardman KD, Sather MR (2002) Opioid dependence treatment, including buprenorphine/naloxone. Ann Pharmacother 36:312-321.

Richards ML, Sadée W (1985) In vivo opiate receptor binding of oripavines to mu, delta and kappa sites in rat brain as determined by an ex vivo labeling method. Eur J Pharmacol 114:343-353.

Sadée W, Rosenbaum JS, Herz A (1982) Buprenorphine: differential inter- action with opiate receptor subtypes in vivo. J Pharmacol Exp Ther 223:157-162.

Selley DE, Sim LJ, Xiao R, Liu Q, Childers SR (1997) mu-Opioid receptorstimulated guanosine-5'-O-(gamma-thio)-triphosphate binding in rat thalamus and cultured cell lines: signal transduction mechanisms underlying agonist efficacy. Mol Pharmacol 51:87-96.

Soyka M, Zingg C, Koller G, Kuefner H (2008) Retention rate and substance use in methadone and buprenorphine maintenance therapy and predictors of outcome: results from a randomized study. Int J Neuropsychopharmacol 11:641-653.

Spagnolo B, Calo G, Polgar WE, Jiang F, Olsen CM, Berzetei-Gurske I, Khroyan TV, Husbands SM, Lewis JW, Toll L, Zaveri NT (2008) Activities of mixed NOP and mu-opioid receptor ligands. Br J Pharmacol 153:609-619.

Teoh SK, Mendelson JH, Mello NK, Kuehnle J, Sintavanarong P, Rhoades EM (1993) Acute interactions of buprenorphine with intravenous cocaine and morphine: an investigational new drug phase I safety evaluation. J Clin Psychopharmacol 13:87-99.

Teoh SK, Mello NK, Mendelson JH, Kuehnle J, Gastfriend DR, Rhoades E, Sholar W (1994) Buprenorphine effects on morphine- and cocaineinduced subjective responses by drug-dependent men. J Clin Psychopharmacol 14:15-27.

Tzschentke TM (2002) Behavioral pharmacology of buprenorphine, with a focus on preclinical models of reward and addiction. Psychopharmacology (Berl) 161:1-16.

Vigezzi P, Guglielmino L, Marzorati P, Silenzio R, De Chiara M, Corrado F, Cocchi L, Cozzolino E (2006) Multimodal drug addiction treatment: a field comparison of methadone and buprenorphine among heroin- and cocaine-dependent patients. J Subst Abuse Treat 31:3-7.

Virk MS, Williams JT (2008) Agonist-specific regulation of $\mu$-opioid receptor desensitization and recovery from desensitization. Mol Pharmacol 73:1301-1308.

Walker EA, Young AM (2001) Differential tolerance to antinociceptive effect of $\mu$ opioids during repeated treatment with etonitazene, morphine or buprenorphine in rats. Psychopharmacology 154:131-142.

West SL, O'Neal KK, Graham CW (2000) A meta-analysis comparing the effectiveness of buprenorphine and methadone. J Subst Abuse 12:405-414.

Wnendt S, Krüger T, Janocha E, Hildebrandt D, Englberger W (1999) Agonistic effect of buprenorphine in a nociceptin/OFQ receptor-triggered reporter gene assay. Mol Pharmacol 56:334-338.

Yamamoto T, Shono K, Tanabe S (2006) Buprenorphine activates mu and opioid receptor like-1 receptors simultaneously, but the analgesic effect is mainly mediated by mu receptor activation in the rat formalin test. J Pharmacol Exp Ther 318:206-213.

Yu Y, Zhang L, Yin X, Sun H, Uhl GR, Wang JB (1997) Mu opioid receptor phosphorylation, desensitization, and ligand efficacy. J Biol Chem 272:28869-28874.

Zaki PA, Keith DE Jr, Brine GA, Carroll FI, Evans CJ (2000) Ligand-induced changes in surface $\mu$-opioid receptor number: relationship to $\mathrm{G}$ protein activation? J Pharmacol Exp Ther 292:1127-1134.

Zhu J, Luo LY, Li JG, Chen C, Liu-Chen LY (1997) Activation of the cloned human kappa opioid receptor by agonists enhances $\left[{ }^{35} \mathrm{~S}\right] \mathrm{GTP}$ gammaS binding to membranes: determination of potencies and efficacies of ligands. J Pharmacol Exp Ther 282:676-684. 